\title{
Поляризация социально-экономического пространства в регионах староосвоенного Центра России: пример Ярославской области
}

\author{
К.В. АВЕРКИЕВА*, Т.Г. НЕФЕДОВА**, Т.Ю. КОНДАКОВА***
}

\begin{abstract}
*Ксения Васильевна Аверкиева - кандидат географических наук, старший научный сотрудник, Институт географии РАН. Адрес: 119017, Москва, Старомонетный пер., д. 29. E-mail: xsenics@yandex.ru

**Татьяна Григорьевна Нефедова - доктор географических наук, главный научный сотрудник, Институт географии РАН. Адрес: 119017, Москва, Старомонетный пер., д. 29. E-mail: trene12@igras.ru

***Татьяна Юрьевна Кондакова - кандидат географических наук, заведующий кафедрой социально-экономической географии и туризма, ФГБОУ ВО «Ярославский государственный педагогический университет им. К.Д. Ушинского». Адрес: 150000, Ярославль, ул. Республиканская, д. 108/1. E-mail: tanijakond7@mail.ru

Цитирование: Аверкиева К.В., Нефедова Т.Г., Кондакова Т.Ю. (2021) Поляризация социально-экономического пространства в регионах староосвоенного Центра России: пример Ярославской области // Мир России. Т. 30. № 1. С. 49-66. DOI: $10.17323 / 1811-038 X-2021-30-1-49-66$
\end{abstract}

В статье рассматриваются процессы поляризации и сжатия освоенного пространства регионов Центра России за пределами Московской области, имеюших продолжительную историю хозяйствования и богатое не только культурное, но и промышленное наследие. Основные исследовательские вопросы касаются выявления предпосылок и сочиально-экономических последствий поляризации социильно-экономического пространства и оценки роли наследия староосвоенности. Рассматриваются эволючия хозяйственного освоения старопромышленных регионов Центральной России и смена его типов, особенности советской индустриализаџии в городах и унификащии сельских районов, а такље постсоветские трансформации

1 Разделы «Староосвоенный Центр: исторический путь и предпосылки к нарастающей поляризации пространства», «Новые траектории индустриального развития», «Старые/новые пути использования наследия» написаны К.В. Аверкиевой и Т.Г. Нефедовой при поддержке проекта Российского научного фонда № 19-17-00174 «Развитие районов старого освоения в условиях социально-экономической поляризации и сжатия освоенного пространства Европейской России»; раздел «Эволюция и современная поляризация сельской местности» подготовлен Т.Ю. Кондаковой и Т.Г. Нефедовой. 
хозяйства. Детально проанализированы основные процессы последних десятилетий: концентрация промышленности, сжатие сельскохозяйственного производства, изменение расселения, современнье миграции. Исследование включало анализ исторической литературь, обработку данньх региональной и мунищипальной статистики и полевых исследований в муниципальных районах Ярославской области, выбранной в качестве ключевого региона. Показано, что региональные центры развиваются благодаря модернизации и реосвоению старых промышленных площадок, созданию новых промышленных парков и постиндустриальных предприятий. Малье города в ичелом стагнируют и теряют население, хотя имеют разные траектории развития, которые определяются широким набором факторов-от географического положения до богатства культурного наследия и наличия активных жителей. Поляризация сельской местности проявляется в нарастании контрастов между пригородами с высокой плотностью населения и хозяйства и территориальными конфликтами, с одной сторонь, и периферией, где стремительно сокращается сельское население, с другой, что свидетельствует о наследуемом советском инварианте организации пространства. Возрождение сельского хозяйства характерно лишь для отдельных очагов и основано на создании новых модернизированных предприятий в ареалах с лучшими природными условиями. Рассматривается противоречивость прочессов модернизации, поляризачии освоенного пространства и использования исторического наследия. Отдельное внимание уделяется роли человеческого потенциала в появлении локальных точек роста. Анализируются возможности не только репродукиии и модернизации прежних видов хозяйствования, но и формирования новых функций, включая рекреационное ландшафтно-культурное и дачное природопользование, возникшие благодаря использованию внутренних и внешних ресурсов.

Ключевые слова: староосвоенный регион, поляризация социально-экономического пространства, расселение, промышленность, сельское хозяйство, переселенческие и трудовые миграции, дачники, Ярославская область

\section{Введение и постановка проблемы}

Категория «старое освоение» неоднократно рассматривалась географами, при этом акцент делался именно на продолжительность хозяйственной деятельности, что позволило вместо анализа освоения как «развития вширь» подойти к его пониманию как смены фаз «жизненного цикла» территориальных образований разного масштаба: зарождение - расцвет - стагнация - кризис - возрождение [Грицай, Иоффе, Трейвиш 1991; Приваловская, Тархов, Трейвии и др. 1995]. Разнообразные примеры российских староосвоенных районов и их современные тренды изучались на примере отдельных регионов [Баринов 2007, Манаков 2014 и др.], их проблемы и примеры приведены в специальном сборнике [Стрелецкий 2019].

Территория современной Центральной России относится к одной из самых староосвоенных. Безусловно, в стране есть и более древние поселения, относящиеся к дославянской культуре, например, древний Дербент на побережье Каспийского моря, древнегреческие поселения Черноморского побережья, городища на Южном Урале и в котловинах юга Сибири. Но если говорить о непрерывном хозяйственном освоении, то Центр России, Волжско-Окское междуречье - наиболее репрезентативный район.

Главный вопрос, обсуждаемый в статье, - это соотношение в пространстве двух противоречивых процессов: модернизации, в т. ч. реиндустриализации староосвоен- 
ных регионов, и поляризации, сжатия освоенного пространства. А.И. Трейвиш выделял два подхода к трактовке понятия «сжатие освоенного пространства»: (1) рост его проницаемости, связности, доступности и (2) сокращение обжитых, освоенных, экономически активных земель [Трейвиш 2010; Трейвиш 2016]. В данной статье рассматривается вторая трактовка понятия «сжатие пространства», которое ассоциируется с его поляризацией, концентрацией населения и хозяйства, появлением ядер развития при уменьшении активной деятельности на остальной территории.

Смена фаз развития и появление точек роста - процессы универсальные, связанные с ходом урбанизации [Gibbs 1963; Friedmann 1966]. В России волны индустриализации и урбанизации, прерываемые войнами, революциями и кризисами, прокатились через весь XX в., вызывая бурное развитие главных центров, притягивающих ресурсы и население [Нефедова, Трейвиш 2017]. К концу века это привело при ограниченных человеческих и финансовых ресурсах к формированию значительных ареалов экономического и демографического истощения, социального опустынивания, в т. ч. в прежде плотно заселенных областях вокруг столичного региона.

Задача исследований состояла в выявлении предпосылок, этапов и последствий поляризации и сжатия социально-экономического пространства в Центре России в XX - начале XXI вв., тесно связанных с процессами индустриализации и урбанизации.

У географов представление о пространстве менялось от понимания развития в пространстве как процесса в некоторой среде с ее ресурсами и расстояниями до производства людьми того социально-экономического пространства, в котором существует человеческое общество [Смирнягин 2016, с. 7-19; Трейвиш 2016, с. 34]. Такое многомерное пространство, хотя и имеет географическую интерпретацию, тем не менее формируется самими людьми и результатами их деятельности. В статье рассматривается, под воздействием каких процессов оно формировалось и менялось, как сложившаяся социально-экономическая структура географического пространства влияет на развитие городов и сельских районов Центра России. При этом единство географического пространства с историческим временем представлено полимасштабно - от верхних макрорегиональных и региональных уровней до нижних, детальных. На примере Ярославской области в сравнении с соседними с ней регионами подробно рассматривается сочетание трансформационных процессов с наследием староосвоенности. Показано, как общие положительные экономические результаты модернизации сочетаются с серьезными социальными последствиями на локальном уровне, приводя к усилению поляризации в географическом пространстве.

Статья, помимо исторических и литературных источников, опирается на использование официальной статистики Росстата по муниципальным районам и населенным пунктам, а также на продолжительные полевые исследования, проведенные авторами в отдельных муниципальных образованиях и поселениях.

\section{Староосвоенный Центр: исторический путь и предпосылки к нарастающей поляризации пространства}

История славянской колонизации этих земель начинается в Х в., когда славянские племена, вытесняя и ассимилируя финно-угорские народы, занимали наиболее 
подходящие для сельского хозяйства территории. Наилучшие условия оказались в районе Владимирского ополья - безлесного участка с плодородными почвами, не характерными для зоны смешанных лесов. По его периметру возникли древние города, в числе которых - Ростов, Суздаль, Переславль-Залесский и Владимир. После объединения земель и возвышения Москвы в Волжско-Окском междуречье формируется ранняя и густая сеть поселений, вырубаются леса, распахиваются удобные для ведения сельского хозяйства земли. От Москвы протягиваются торговые пути, связывающие ее с другими городами, формируются транзитные коридоры, на которых возникают города и сельские центры народных промыслов. На базе крестьянских кустарных занятий появляются промышленные производства: первыми стали текстильные предприятия в треугольнике Москва - Ярославль - Владимир (с наибольшей концентрацией на территории современной Ивановской области), позже к ним добавились мануфактуры вдоль тракта, связывавшего Москву и Санкт-Петербург. Екатерининский запрет на размещение энергоемких производств вблизи столиц способствовал развитию ареалов стекольных и фарфорово-фаянсовых предприятий: линейный (вдоль Санкт-Петербургского тракта) и несколько кустов (наиболее крупный - в Мещере с центром в городе Гусь-Хрустальный). По мере развития железнодорожного строительства в ХIX в. в городах Центральной России стали возникать вагоно- и локомотивостроительные производства; машиностроение развивалось и в волжских городах, где велось строительство судов. На базе аграрного производства выросли первые, иногда довольно крупные производства: так, Ярославская губерния стала основным в Российской империи регионом производства крахмала, что впоследствии превратило ее в один из первых центров отечественной химической индустрии.

На рубеже XIX-XX вв. доля сельских жителей в окружающих Москву регионах составляла 87-89\%, а их плотность, например, в Ярославской губернии, достигала 28 человек на кв. километр (как в современном Краснодарском крае). Невысокое плодородие почв (не считая плодородного ополья, котловин крупных озер и пойменных почв в долинах крупных рек) стимулировало развитие крестьянской промышленности и отходничества. Отхожими промыслами занимались в начале XX в. свыше 20\% мужского трудоспособного населения окружающих Москву губерний [Рыбников 1929], при этом статистика не учитывала долю занятых в промыслах и в производственной деятельности на местах.

В начале XX в. экономический рост староосвоенного центра базировался, с одной стороны, на выгодах географического положения (судоходная Волга, близость к Москве и плотная дорожная сеть), с другой, на изобилии рабочих рук, усилившемся благодаря демографическому переходу, и на предприимчивости сельских жителей, искавших в условиях малоземелья и невысокого плодородия почв различные неаграрные занятия.

Советская модель экономики была несовместима с самодеятельными промыслами и купеческими традициями предпринимательства: отходничество было ликвидировано, капиталистые крестьяне ${ }^{2}$ раскулачены, промыслы объединены в артели и тресты. Экономика областей Центра после шоковых событий (национализации фабрик, бегства фабрикантов и массовых арестов

\footnotetext{
2 Капиталистые крестьяне - по сути, крестьяне-предприниматели, они могли быть как крепостными, так и свободными, например, выкупившимися на волю (Бессолиџын 2006, с. 85-89; Сметанин 2005).
} 
инженеров), опираясь на дореволюционное промышленное наследие, пошла по пути утяжеления и укрупнения. При сохранении старых отраслей начали формироваться новые, ориентированные не столько на использование местных ресурсов и преимуществ положения, сколько на кооперацию с динамично развивающимся хозяйственным комплексом Москвы. Столица должна была сочетать в себе наиболее передовые отрасли промышленного производства, а в староосвоенных областях Центра строились вспомогательные заводы. В единых условиях плановой экономики началось напластование различных технологичных укладов, где дореволюционные текстильные предприятия соседствовали с заводами электроники (на то время высокотехнологичными). Сходная ситуация наблюдалась и в сельском хозяйстве. На территории всех центральных регионов формировалась колхозно-совхозная система с почти универсальным набором отраслей специализации при постоянном расширении доли зерновых культур. Правда, были и исключения: например, котловина озера Неро в Ростовском районе, где колхозная система имела более сложную организацию в кооперации с традиционными здесь частными овощными хозяйствами [Саушкин 1947, с. 174].

С 1970-х гг., несмотря на растущие затраты на поддержку сельского хозяйства, во многих нечерноземных областях за пределами Московской области фиксируется уменьшение урожайности культур и продуктивности скота [Нефедова 2013, с. 61-62]: в Ярославской области объемы производства сельскохозяйственной продукции стали сокращаться на 2-6\% каждую пятилетку [Народное хозяйство 1991, с. 174]; обозначилось сжатие сельскохозяйственных угодий с 1,5 млн га в 1970 г. до 1,1 млн га в 1990 г.

Стремительная индустриализация и рост городов, особенно региональных центров, сочетались с избирательным инфраструктурным наполнением сельской местности. Электричество к небольшим деревням подводили выборочно, дороги строились преимущественно к центральным усадьбам колхозов еще до начала кампании сселения неперспективных деревень. На этом фоне выдача паспортов сельским жителям усилила отток из сельской местности и рост городов, особенно крупных.

Таким образом, можно утверждать, что процессам сильной сельской депопуляции и поляризации освоенного пространства старт был дан еще в советское время, хотя его физическое сжатие отчасти тормозилось поддержкой сельского хозяйства и жестким контролем над уменьшением посевных площадей и поголовья скота.

\section{Новые траектории индустриального развития}

В постсоветский период поляризация усилилась ввиду потерь населения малыми и средними городами, обусловленных кризисом местообразующих предприятий. Региональные центры оказались в лучшем положении благодаря как диверсифицированной экономике и наличию более современных производств, так и за счет административного статуса, что стимулировало формирование новых и разнообразных траекторий развития регионов старопромышленного Центра.

После непродолжительного шока наиболее промышленно развитые Ярославская, Ивановская и Владимирская области пошли по пути реиндустриализации, опираясь на сложившиеся традиции и навыки населения, потенциал высших 
и технических образовательных учреждений. Владимирская область в числе первых начала принимать предприятия пищевой промышленности, перемещенные за пределы Москвы, или создавать новые, которые изначально планировалось построить вне столицы. Постепенно стали появляться предприятия и в традиционном для Владимирской области машиностроении, по-прежнему ориентированные на столичные потребности (электробусы, бытовая техника, навигационные приборы). В Ивановской области на фоне падения производства большинства видов продукции начала возрождаться текстильная отрасль: регион вернул себе позиции если не ситцевого, то хотя бы трикотажного края. В Ярославской области одновременно с модернизацией наиболее крупных производств (нефтехимия, химия, машиностроение) были построены новые предприятия, ориентированные на столичные рынки (строительная техника, стройматериалы, фармацевтика). Наряду с реальным сектором развивалась и третичная сфера за счет возрастания роли различных государственных услуг, размещения логистических центров, офисов телекоммуникационных корпораций и развития туристической инфраструктуры.

Тверская и Костромская области, исторически менее индустриальные, на фоне старопромышленного ядра немного теряются, имея куда более низкую плотность населения и разреженную сеть малых городов. Если Тверская область еще может извлекать выгоды из своего транзитного межстоличного расположения (вдоль полимагистрали возникают новые очаги экономического развития), то Костромская область усиливает свою периферийность и существует, как и прежде, в большей степени за счет эксплуатации природных, прежде всего лесных, ресурсов.

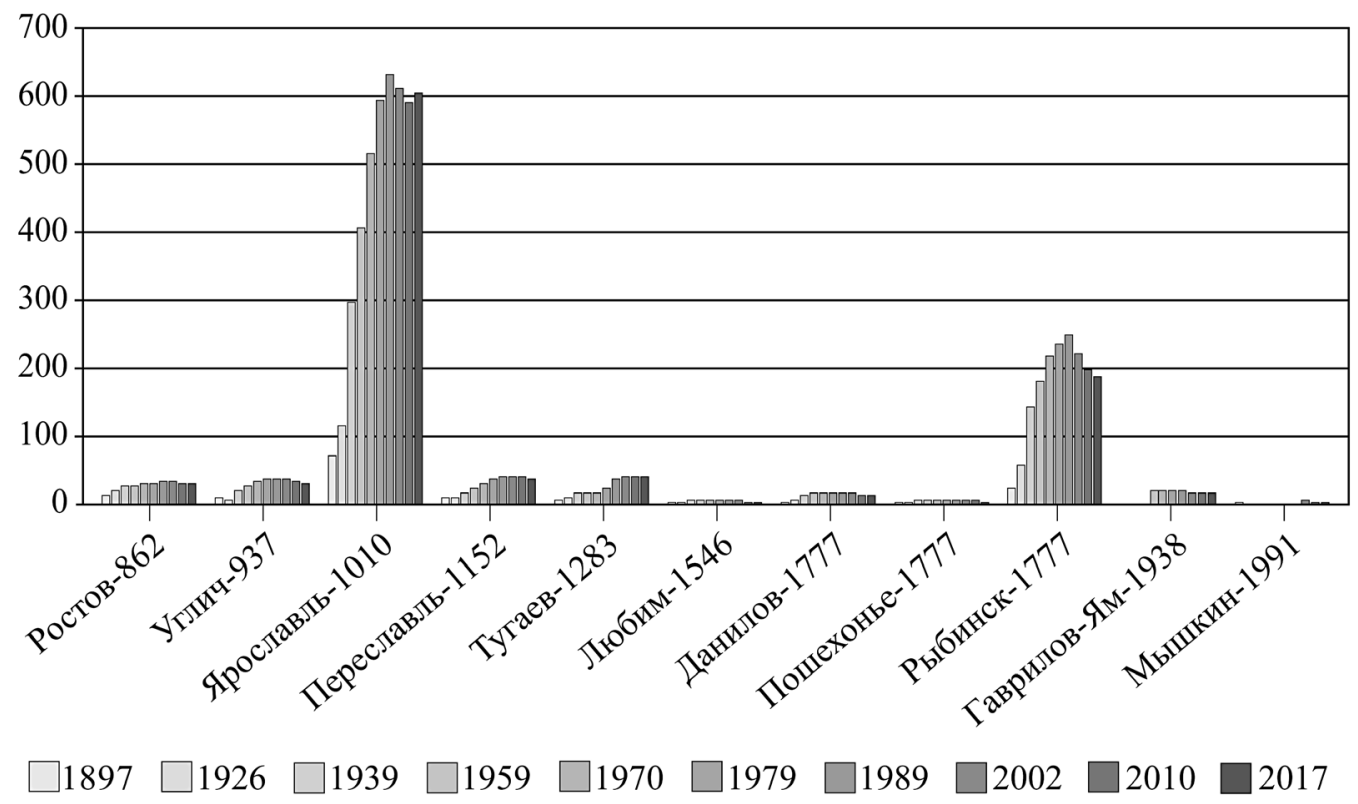

Рисунок 1. Число жителей в городах Ярославской области с 1987 по 2017 г. с указанием даты основания города, по материалам переписей населения и текущим данным Росстата 


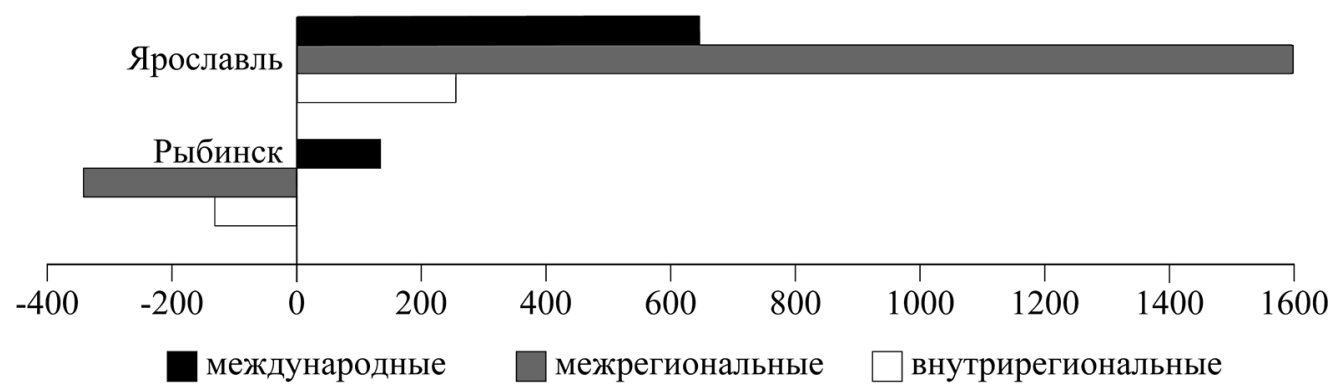

Рисунок 2. Миграционный прирост/убыль населения в Ярославле и Рыбинске в среднем в 2015-2017 гг., человек (с учетом места выхода или отъезда мигрантов)

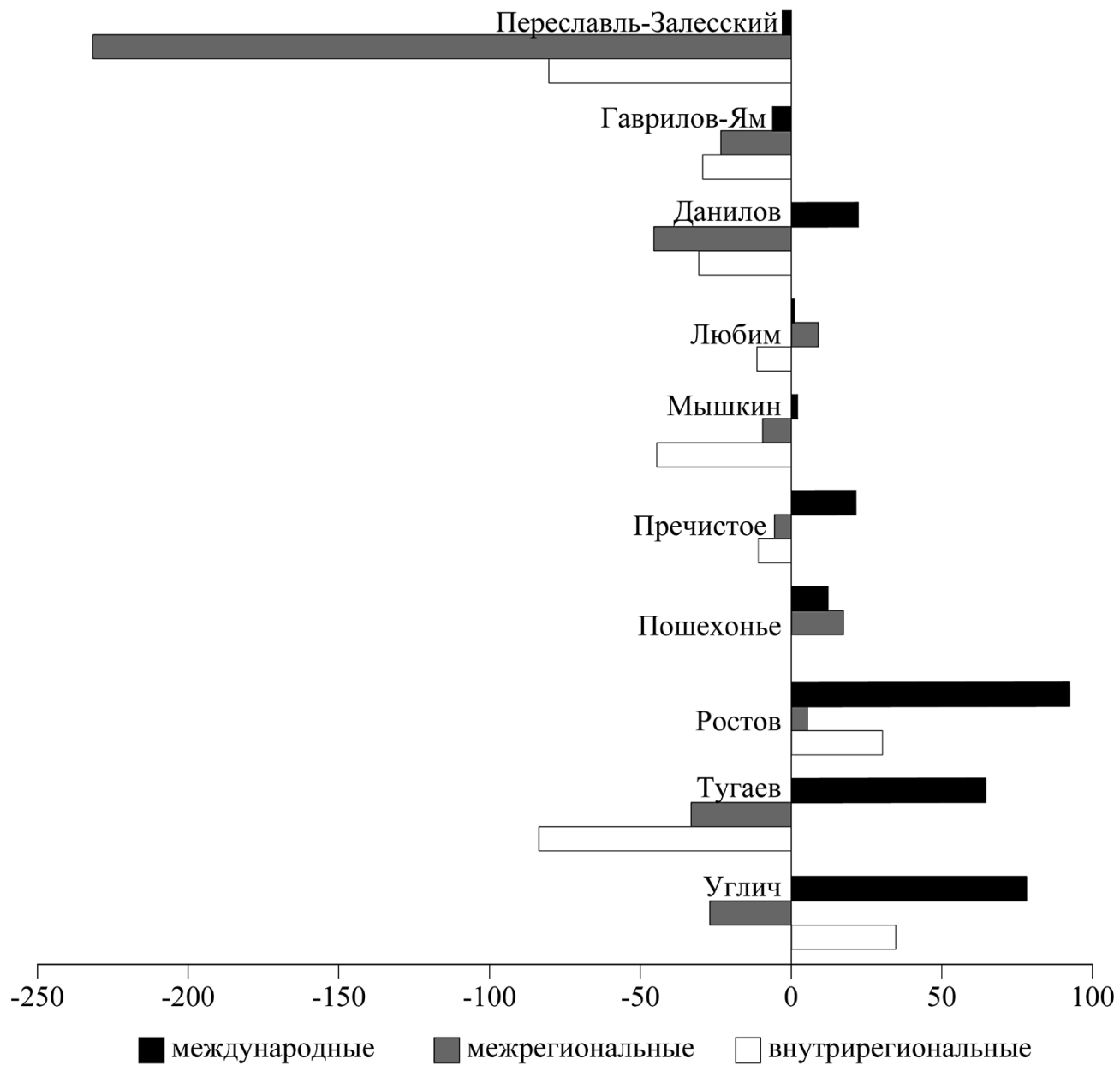

Рисунок 3. Миграционный прирост/убыль населения в прочих городах Ярославской области в среднем в 2015-2017 гг., человек

(с учетом места выхода или отъезда мигрантов) 
Следует отметить, что при нарастании межрегиональных контрастов области староосвоенного Центра сочетают в себе, с одной стороны, процессы восстановительного роста экономики и модернизации/трансформации хозяйственного комплекса, а с другой стороны, процессы поляризации освоенного пространства, которая проявляется в опережающем росте региональных центров на фоне депопуляции малых городов и сельских территорий (не считая пригородов) и в усилении межрайонных контрастов в социально-экономическом развитии. Эти процессы можно продемонстрировать на примере Ярославской области, где динамично развивается региональный центр - наиболее крупный город в окружении Москвы, и в то же время даже такой сравнительно небольшой регион подвержен процессам поляризации. Концентрация рабочих мест в Ярославле и Рыбинске и бурная урбанизация ХX в. способствовали тому, что 2/3 из 1,3 млн жителей области сосредоточились в двух главных городах. Однако если людность Ярославля в целом сохраняется, то Рыбинск относится к «сжимающимся» большим городам: с 1989 г. он потерял свыше четверти жителей из-за сокращения рабочих мест, в основном на машиностроительных предприятиях (рисунок 1).

Современные тенденции внутренних миграций населения на постоянное место жительства показывают продолжающееся стягивание населения области в ее столицу (рисунок 2). Ярославль, в отличие от Рыбинска, остается также весьма привлекательным и для населения соседних регионов, в т. ч. студентов, а также для международных мигрантов. Малые города чаще теряют население и привлекают лишь выходцев из бывших советских республик (рисунок 3). В лучшем положении оказались некоторые исторические центры на маршруте Золотого кольца (Ростов, Углич).

\section{Эволюция и современная поляризация сельской местности}

Более детальный анализ эволюции систем сельского расселения в Ярославской области доказывает, что поляризация и сжатие - явления не пост- и даже не позднесоветского периодов. На протяжении истории уже были волны расширения и сокращения населенного пространства, а непрерывное уменьшение числа населенных пунктов началось еще в первой половине XX в.

В Ярославской области исторически сформировалась дисперсная система расселения, состоявшая из разорванных (островных) ландшафтно-хозяйственных ареалов и легко подвергавшаяся «размыванию» при изменении социально-экономических условий. При том, что активное освоение земельных угодий и рост числа деревень наблюдались с XVI-XVII вв., уже в конце XVIII в. на водоразделах и вдали от крупных дорог началось сокращение числа сельских населенных пунктов [Ярославская губерния 1865]. С середины XIX в. до начала XX в. их число вновь увеличилось, и большую часть новых населенных пунктов, особенно после отмены крепостного права, составили деревни и хутора с 15-20 жителями.

Для первых двух десятилетий советской власти было характерно резкое редуцирование числа сельских населенных пунктов (на 15-20\%), в т. ч. из-за разрушения церковно-приходской сети, которая выполняла функции опорной социальной инфраструктуры. Во второй половине XX в. произошло дальнейшее сокращение 
количества сельских населенных пунктов, особенно на периферии области, но появлялись и новые - рабочие поселки лесного и дорожного хозяйства; часть из них к настоящему времени также исчезла, но самые крупные сохранились. Наиболее серьезная убыль сельского населения пришлась, как и по всей Центральной России, на 1930-1960-е гг., время стремительной индустриализации, урбанизации, политических репрессий и войны. Но и в 1970-1980-х гг., несмотря на программу развития сельской местности Нечерноземья, сельское население продолжало сокращаться. Если в 1926 г. в Ярославской губернии (по территории она почти совпадает с современной Ярославской областью) жили свыше 1,14 млн сельских жителей, то в 1970 г. - 420 тыс., а в 1989 г. - 270 тыс. (в 4 раза меньше), в настоящее время - 231 тыс. человек. Сохранилось всего 35\% от числа селений, существовавших в середине XIX в.

Еще полтора века назад в сельских населенных пунктах Ярославской области на один двор приходилось в среднем 6-7 человек (редко до 10), а людность населенных пунктов насчитывала 50-250 человек. В настоящее время населенные пункты, где проживают менее 10 жителей, составляют 40-50\%, более чем в 95\% населенных пунктов зарегистрировано менее 50 человек, а в 20\% деревень не зарегистрировано ни одного постоянного жителя. Почти половина сельского населения сосредоточена в пунктах людностью 500 и более жителей с центральными усадьбами сельхозпредприятий и агрохолдингов, где сохранился базовый набор социальной инфраструктуры.

Современная депопуляция сельской местности усугубляется процессами оптимизации социальной инфраструктуры, в первую очередь школ. Именно закрытие учебных заведений, особенно начальных, стало триггером, запустившим процесс омертвления целых фрагментов расселенческой сети: так, в Ярославской области за первое десятилетие XXI в. закрылось 30 школ, но количество исчезающих при этом населенных пунктов составляет пятикратную величину, и последняя волна объединения поселений еще больше усилила отток жителей из сельской местности.

Уже к концу советского периода во всех староосвоенных областях Центра России проявились сильные различия в динамике сельского населения между пригородами областных центров и периферийными районами [Нефедова 2013, с. 166-171]. В настоящее время пригородно-периферийная организация сельской местности воспроизводится в принципиально иных институциональных и экономических условиях. В Ярославской области все муниципальные районы за пределами пригорода Ярославля продолжают терять население, хотя и не такими темпами, как в советское время (рисунок 4). Пригородный Ярославский район даже опережает областную столицу по приему внутрирегиональных мигрантов, продолжая стягивать население со всей области ближе к центру. Следует отметить, что эти процессы типичны для областей современного Нечерноземья [Карачурина, Мкртчян 2016; Мкртчян 2019]. В 2018 г. в пригороде Ярославля доля населения старше трудоспособного возраста составляла 25\%, на полупериферии в результате отъезда молодежи она увеличилась до $35 \%$, а на северной периферии области достигла $40 \%$ и более. При этом незначительный миграционный прирост в сельскую местность Ярославской и других областей Центра в последние годы обеспечивают исключительно международные мигранты, большая часть которых работает в Ярославле, Москве и Московской области. 


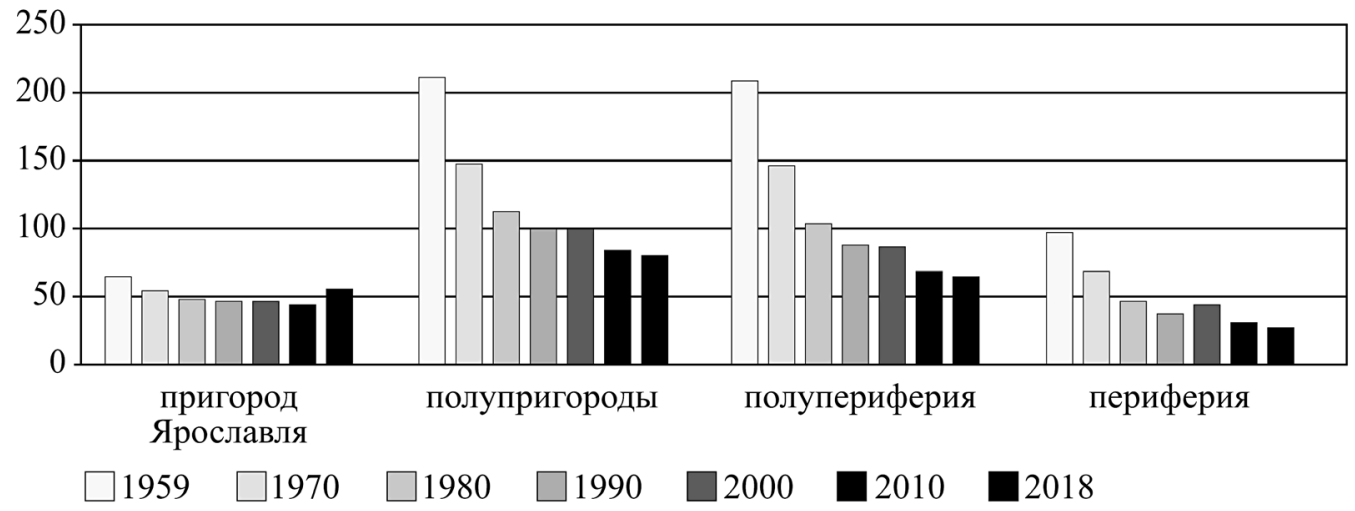

Рисунок 4. Численность сельского населения в Ярославской области во второй половине XX - начале XXI вв. в муниципалитетах разной степени удаленности от областного центра, тыс. чел.

(пригород - Ярославский муниципальный район, полупригороды районы-соседи второго порядка, полупериферия - соседи третьего порядка к областному центру, периферия - остальные муниципальные районы) Источники: [Демографические процессы 1996], данные Росстата по муниципальным образованиям.

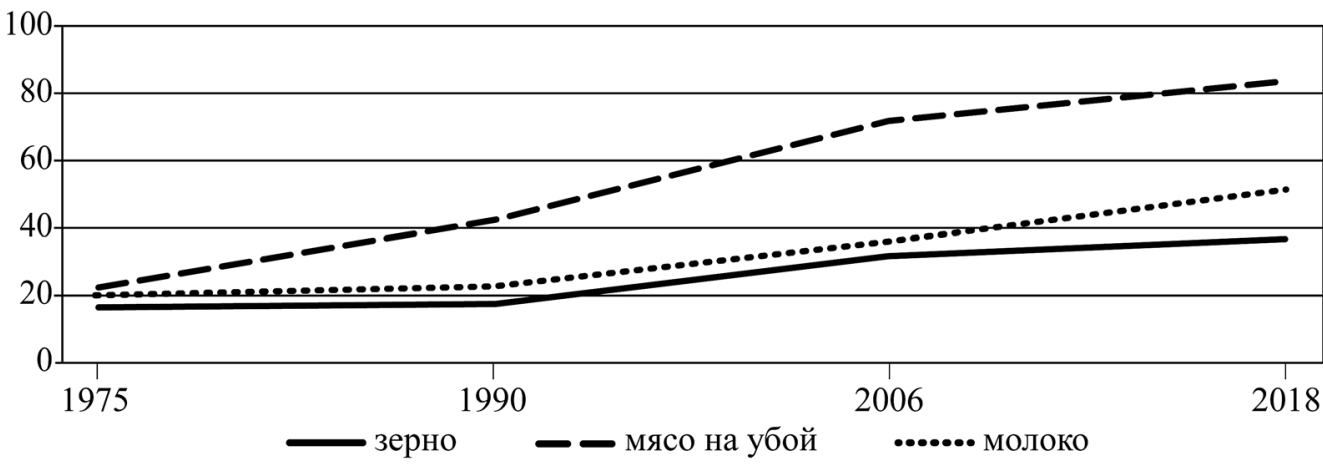

Рисунок 5. Доля двух районов-лидеров Ярославской области в производстве сельскохозяйственной продукции с 1975 по 2018 г., \%

Источники: [Народное хозяйство 1991; Ярославия 2019].

В постсоветское время с появлением современных технологий и новых типов полуиндустриальных предприятий сельское хозяйство, как и в других регионах России [Шагайда, Узун 2019; Нефедова 2017], пережило серьезную модернизацию: так, в Ярославской области в 2018 г. осталось 40\% от посевной площади 1990 г. [Регионы России 1996; Регионы России 2018]; традиционное для Нечерно- 
земья льноводство сократилось многократно. Тем не менее при сокращении производства зерна (в 2018 г. в области собирали лишь 18\% к 1990 г.) производство мяса выросло до 102\% [Народное хозяйство 1991; Ярославия 2019], в основном за счет новых животноводческих, в т. ч. птицеводческих, комплексов, ориентирующихся на привозные корма.

Постепенно область, не обладающая высоким агроклиматическим потенциалом, отказалась от многих советских отраслей специализации, но не повсеместно, что только усиливало внутрирегиональные контрасты. Если в 1975 г. два района-лидера - Ярославский и Ростовский - производили 15\% областного объема зерна, то в 2018 г. - 38\%, хотя в них осталось 40 и 25\% прежнего производства соответственно (рисунок 5), при этом потери в остальных районах были гораздо больше. Картофелеводческая и овощеводческая специализация сейчас распространены лишь в частных хозяйствах, особенно в Ростовском ареале у озера Неро; здесь меньше заброшенных земель в хозяйствах населения, больше фермеров и мелких предпринимателей. Обследование показало, что не только местные жители, но и уехавшие в города наследники продолжают выгодный овощной бизнес на участках, ставших дачными. Эти традиции особенно заметны на трассе Москва - Ярославль в районе Ростова, где местные жители и перекупщики предлагают овощи (особенно знаменитый ростовский лук), соленья, рыбу, а в сезон грибы и ягоды.

В настоящее время животноводство сосредотачивается в местах наибольшего спроса: в пригородах Ярославля и Рыбинска сейчас производится 85\% мяса (рисунок 5), в то время как в советский период оно было рассредоточено более равномерно: тогда два лидера (Ярославский и Переславский районы) давали лишь $13 \%$ областного производства мяса. Сейчас доля двух районов-лидеров в производстве молока увеличилась с 10 до 51\%; помимо пригорода Ярославля на юге области лидирует Борисоглебский район, работающий в основном на московский регион; в Угличском и Переславском районах малых производителей стимулирует устойчивый спрос на молочную продукцию туристов и дачников; в Переславском районе из-за близости к московской агломерации развиты и нестандартные виды деятельности (разведение оленей, страусов и др.). Отдельные фермерские хозяйства, в т. ч. с небольшими магазинами, организуются горожанами Переславля, Ростова или москвичами, что характерно и для других районов в окрестностях московской агломерации [Пивовар и др. 2018].

Обследование сельских поселений и предприятий продемонстрировало, что выжили и укрепились в последние 30 лет единицы, и большая их часть сосредоточена вокруг Ярославля ${ }^{3}$, хотя отдельные очаги возрождения наблюдаются и в других районах области. Важным фактором сохранения сельского хозяйства стали внешние инвестиции из крупных городов: например, плодородные земли бывшего совхоза «Овощевод» рядом с озером Неро выкупил столичный агрохолдинг ЗАО «Белая дача», помимо этого, инвестируются и традиционные местные предприятия ${ }^{4}$.

\footnotetext{
3 Еще в советское время Г.В. Иоффе была замечена взаимозависимость трансформации социальных и экономических пространственных структур [Иоффе 1990].

4 Например, ЗАО «Пореченский консервный завод», известный с дореволюционных времен.
} 


\section{Старые/новые пути использования наследия}

Все регионы в центре России сохранили большое количество исторических памятников, что стимулирует развитие туризма: в 2017 г. города Золотого кольца были самыми посещаемыми в России (после Краснодарского края, Московского региона и Крыма) [Топ-50 2017]. В Ярославской области наряду с Переславлем, Ростовом Великим, Ярославлем, Угличем и Тутаевом развиваются и другие центры притяжения туристов. Однако близость к Москве является не только преимуществом, но и в определенной мере недостатком, вынуждающим искать нестандартные пути привлечения туристов: например, обновленная гостиница в Переславле-Залесском в 150 километрах от Москвы даже в туристический сезон остается пустой, а группы организованных туристов, погуляв в городе, едут ночевать в Ростов, а чаще в Ярославль, привлекающий их гораздо большим разнообразием услуг.

Сохранившиеся традиции если не меценатства, то инвестиций в культурное наследие проявляются и в нестандартных проектах: так, один из ярославских предпринимателей осуществляет комплексную ревитализацию крупного села Вятского в Некрасовском районе, реставрируя исторические сельские дома, возрождая местные производства, создавая музеи и места размещения туристов. Ярославская предприимчивость, известная в прошлые века [Горошников 2018], способствовала созданию нескольких десятков частных музеев, рассредоточенных по городам и селам. Возрождаются утраченные в советские годы промыслы, например, производство изразцов. Да и сама трасса М8 в пределах Ярославской области, особенно на участке от Переславля-Залесского до Ярославля, отличается от других магистралей, расходящихся от Московской области, обилием магазинчиков, кафе, ресторанов и небольших музеев.

Туризм, хотя и рассматривается в стратегиях регионального развития областей, окружающих московский регион, как один из локомотивов экономики, в современных условиях даже при богатом историческом наследии не становится альтернативой традиционным отраслям. Концентрация промышленности в крупных городах и пространственная поляризация сельского хозяйства стали причиной резкого уменьшения официальных рабочих мест в малых городах и сельских районах, особенно после оптимизации сети социальной инфраструктуры. В 2017 г. доля занятых в организациях разного профиля, включая бюджетную сферу, в регионах вокруг Московской области составляла в муниципальных районах, по данным Росстата, от 30 до 50\% населения в трудоспособном возрасте, что стимулировало рост возвратной пространственной мобильности населения на заработки в Москву и Московскую область (возрождение дореволюционного отходничества) [Нефедова, Аверкиева, Махрова 2016].

Важным фактором частичного сглаживания поляризации служит появление в сельской местности и малых городах сезонного дачного населения, в т. ч. из Москвы. Москвичи и петербуржцы выезжали на дачи и до революции, но зоны их распространения не были столь обширны. Сейчас большую часть дач составляют возникшие в советское время садовые и дачные товарищества, современные коттеджные поселки, дома в которых также часто используются как второе дачное жилье, и все более популярные дома горожан в деревнях [Аверкиева, 
Нефедова 2016]. Дачники оказывают существенное влияние на сельскую местность и малые города, их роль можно показать на примере Переславского района Ярославской области у границы с Московской областью, в котором в 2018 г. из 44 садоводческих товариществ 18 были московскими; в остальных около половины участков также перекуплено москвичами. Местная администрация оценивает летнюю прибавку населения вокруг Переславля только в садовых товариществах в 13 тыс. человек при 20 тыс. сельских жителей. Обследование деревень в разных сельских округах показало, что число домов, купленных горожанами (чаще москвичами), почти равно числу домов сельских жителей, а в некоторых деревнях дач больше, чем домов сельчан. Это делает население района пульсирующим по сезонам года и составляет существенную добавочную сезонную нагрузку на дорожную и социальную инфраструктуру. При этом наплыв горожан, формируя столь обширные зоны сезонной дезурбанизации, способствует созданию неформальных рабочих мест благодаря строительству, ремонту домов, уходу за участками, а также увеличению спроса на продукцию местных производителей, включая личные подсобные хозяйства.

\section{Заключение}

Главными стимулами развития регионов Центральной России и в советское время, и в последние годы служат диффузия инноваций и инвестиций из Москвы и ее огромный потребительский спрос, при этом столица продолжает поглощать население окружающих регионов, что инициирует противоречивые тенденции в их современной трансформации.

В настоящее время для регионов вокруг московской агломерации характерны возобновление промышленного развития и размещение новых отраслей, что отчасти напоминает стремительный рост конца XIX в. Если в советские годы промышленность в большей степени обслуживала производственный комплекс Москвы, то сейчас большинство предприятий поставляет продукцию по всей России.

Исторический подход позволил проследить влияние смены укладов на пространственную поляризацию. Ее усиление в постсоветский период свидетельствует о том, что после советской унификации разные регионы и районы находятся в поиске своих экономических ниш, уходя от не всегда эффективных отраслей и адаптируясь к новым условиям.

Даже на небольшом удалении от Москвы при сравнительно незначительных площадях для регионов центра России характерны очень сильные контрасты между крупными и малыми городами, пригородной и периферийной сельской местностью, которые обозначились в XIX в., оформились в советское время и усилились в постсоветские годы при резкой трансформации экономических условий. Наличие рабочих мест в крупных городах влечет за собой пролонгирование урбанизации и оттока населения на постоянное место жительства или на временные работы из малых городов и сельской местности в региональные центры или московскую агломерацию. Замедлить эти процессы можно только приданием большей самостоятельности низовым ячейкам, поддержкой в них ключевой социальной инфраструктуры рабочих мест и любых форм среднего и малого бизнеса. 
Ярославская область служит наглядным примером сложного сочетания специфики географического положения, накопленных традиций и современных направлений трансформации, приводящих к усилению поляризации социально-экономического пространства. Ее пример демонстрирует, что возрождение идет в отдельных очагах, где наблюдается грамотное сочетание исторического наследия и модернизации, в т. ч. связанной с приходом новых внешних инвестиций.

Постиндустриальное развитие Москвы не привело к выраженной дезурбанизации, а, скорее, усилило урбанизацию и частично субурбанизацию в ближайших к ней пригородных зонах. Это связано со сравнительно большими российскими расстояниями, со слабой обустроенностью сельской местности и с недостатком рабочих мест за пределами Московской агломерации. Но важным фактором остается российская традиция жизни на два дома, позволяющая сочетать преимущества городского и сельского/полусельского образа жизни в разные сезоны года. Массовость дач и распространение дач москвичей за пределы Московской области указывают на то, что при длительном количественном и качественном истощении богатейшего в прошлом человеческого капитала развитие окружающих Московский регион областей может базироваться не только на привычных отраслях экономики, но и на внедрении новых элементов, включая рекреационное ландшафтно-культурное и дачное природопользование. Многочисленные малые деревни можно рассматривать не как проблему, а как потенциал реосвоения территории горожанами хотя бы для временного пребывания, учитывая близость к московскому региону. Расширение туристической и дачной значимости этих территорий влечет за собой появление новых инициатив, поскольку в эти регионы хотя бы временно или сезонно приезжает образованное, часто обеспеченное, активное городское население, что способствует созданию новой социальной среды. Рекреационный потенциал этих староосвоенных районов явно недооценивается, а централизация бюджетной политики лишает местные власти возможностей более гибкой адаптации к изменению векторов социально-экономического развития территории.

\section{Литература}

Аверкиева К.В., Нефедова Т.Г. (2016) Дачная «колонизация» российской глубинки. Пример Костромской области // Мир России. Т. 25. № 1. С. 103-128.

Баринов С.Л. (2007) Социально-экономическая периферийность в староосвоенных регионах Центра и Северо-Запада России // Региональные исследования № 3(13). C. 26-32.

Бессолицын А.А., Кузьмичев А.Д. (2006) Экономическая история России: очерки развития предпринимательства. М: ВШЭ.

Всероссийская сельскохозяйственная перепись 2016 года (2017). Том. 2. М.: ИИЦ «Статистика России».

Горошников В.В. (ред.) (2018) Ярославский характер. Рыбинск: Медиарост.

Грицай О.В., Иоффе Г.В., Трейвиш А.И. (1991) Центр и периферия в региональном развитии. М.: Наука.

Демографические процессы в Ярославской области за 60 лет (1996). Ярославль: Ярославский областной комитет государственной статистики. 
Иоффе Г.В. (1990) Сельское хозяйство Нечерноземья: Территориальные проблемы. М.: Наука. Карачурина Л.Б., Мкртчян Н.В. (2016) Роль миграции в усилении контрастов расселения на муниципальном уровне в России // Известия РАН. Серия географ. № 5. С. 46-59.

Манаков А.Г. (2014) Методика историко-географического районирования староосвоенных территорий на микроуровне (на примере Псковской области) // Псковский регионологический журнал. № 19. С. 83-96.

Мкртчян Н.В. (2019) Миграции в сельской местности России: территориальные различия // Население и экономика. № 1(3). C. 39-51. DOI: 10.3897/popecon.3.e34780

Народное хозяйство Ярославской области в 1990 году (1991). Статистический сборник. Ярославль: Госкомстат РСФСР Ярославское областное управление статистики.

Нефедова Т.Г. (2013) Десять актуальных вопросов о сельской России: ответы географа. М.: URSS-ЛЕНАНД.

Нефедова Т.Г. (2017) Двадцать пять лет постсоветскому сельскому хозяйству России: географические тенденции и противоречия // Известия РАН. Серия географическая. № 5. C. $7-18$.

Нефедова Т.Г., Аверкиева К.В., Махрова А.Г. (ред.) (2016) Между домом и... домом. Возвратная пространственная мобильность населения России. М.: Новый хронограф.

Нефедова Т.Г., Трейвиш А.И. (2017) Перестройка расселения в современной России: урбанизация или дезурбанизация? // Региональные исследования. № 2(56). С. 12-23.

Пивовар Г.А., Алексеев А.И., Гавриленко А.С., Гусаков Т.Ю., Дельва К.И., Корюхин Д.М. (2018) Рост полифункциональности сельской местности: пример района на границе Московской агломерации // Вестник Московского университета. Серия 5. География. № 2. C. $102-104$.

Приваловская Г.А., Тархов С.А., Трейвиш А.И. и др. (ред.) (1995) Территориальная структура хозяйства староосвоенных районов. М.: Наука.

Регионы России (1996). М.: Федеральная служба государственной статистики.

Регионы России (2018). М.: Федеральная служба государственной статистики.

Рыбников А.А. (1929) Перенаселение и борьба с ним // Баранский Н.Н. (ред.) Экономическая география: хрестоматия. Т. II. СССР. М. Изд-во комуннистического Университета им. Я.М. Свердлова. С. 60-111.

Саушкин Ю.Г. (1947) Географические очерки природы и сельскохозяйственной деятельности населения в различных районах Советского Союза. М.: ОГИЗ.

Сметанин С.И. (2005) История предпринимательства в России: Курс лекций. М.: Логос.

Смирнягин Л.В. (2016) Судьба географического пространства в социальных науках // Известия РАН. Серия географическая. № 4. С. 7-19.

Стрелецкий В.Н. (ред.) (2019) Староосвоенные районы: генезис, исторические судьбы, современные тренды развития. М.: ИП Матушкина.

Топ-50: Самые туристические регионы России, популярные в 2017 году (2017) // ТурСтат // http://turstat.com/travelrussia2017

Трейвиш А.И. (2010) «Сжатие» пространства: трактовка и модели // Артоболевский С.С., Синцеров Л.М. (ред.) Сжатие социально-экономического пространства: новой в теории регионального развития и практике его государственного регулирования. М.: Эслан. С. 16-32.

Трейвиш А.И. (2016) Мобильность и развитие общества в пульсирующем пространстве // Синцеров Л.М. (ред.) География мирового развития. Выпуск 3: Сборник научных трудов. М.: Товарищество научных изданий КМК. С. 16-39.

Шагайда Н.И., Узун В.Я. (2019) Драйверы роста и структурных сдвигов в сельском хозяйстве России. Научные доклады РАНХиГС. № 4(19). М.: Дело.

Ярославия - города и районы области за 2018 год (2019). Ярославль: Территориальный орган федеральной службы государственной статистики по Ярославской области.

Ярославская губерния: Список населенных мест по сведениям 1859 года (1865). Центральный статистический комитет Министерства внутренних дел. СПб.: Типография Карла Вульфа.

Gibbs J. (1963) The Evolution of Population Concentration // Economic Geography, no 2, pp. 119-129.

Friedmann J. (1966) Regional Development Policy. A Case Study of Venezuela, Cambridge: Mass. Inst. Tech. Press. 


\title{
Spatial Socio-economic Polarization in the Central Developed Regions of Russia: The Case of Yaroslavl Oblast
}

\author{
K. AVERKIEVA*, T. NEFEDOVA**, T. KONDAKOVA***
}

\begin{abstract}
*Kseniya Averkieva - PhD in Geography, Senior Researcher, Institute of Geography of the Russian Academy of Sciences. Address: 29, Staromonetnyj Lane, Moscow, 119017, Russian Federation. E-mail: xsenics@yandex.ru

**Tatyana Nefedova - DSc in Geography, Chief Researcher, Institute of Geography of the Russian Academy of Sciences. Address: 29, Staromonetnyj Lane, Moscow, 119017, Russian Federation. E-mail: trene12@igras.ru

***Tatyana Kondakova - PhD in Geography, Head of the Department of Socio-economic Geography and Tourism of the Yaroslavl State Pedagogical University named after K.D. Ushinsky. Address: 108/1, Republican St., Yaroslavl, 150000, Russian Federation. E-mail: tanijakond7@mail.ru
\end{abstract}

Citation: Averkieva K., Nefedova T., Kondakova T. (2021) Spatial Socio-economic Polarization in the Central Developed Regions of Russia: The Case of Yaroslavl Oblast. Mir Rossii, vol. 30, no 1, pp. 49-66 (in Russian). DOI: 10.17323/1811-038X-2021-30-1-49-66

\begin{abstract}
In this article, we consider the polarization and shrinkage in the space of the early developed regions of central Russia, outside Moscow Region. The areas feature a rich cultural and industrial heritage and a long history of economic development. The main focuses are to identify the prerequisites and socio-economic consequences of spatial polarization and to understand to what extent these are influenced by the legacies of the past. We describe the evolution of economic development in the old industrial regions of central Russia, the features of Soviet industrialization in cities and the unification of rural areas, and postSoviet economic transformations. We then analyze in detail the key processes of the last decades: industrial concentration, the compression of agricultural production, changes in settlement arrangements, and modern migration. The study is based on the historical literature, regional and municipal statistical data, and field research in the municipal districts of the Yaroslavl Oblast which was chosen as a representative region. We show that regional centers continue expanding, bolstered by the modernization and re-development of old industrial sites, the creation of new industrial parks and post-industrial enterprises. Small cities are losing population, although they may feature different developmental paths determined by a wide range of factors, from geographical location to the richness of their cultural heritage and the presence of active residents. The polarization of rural areas is reflected in the growing contrasts between highly populated suburbs and the periphery, where the rural population is rapidly declining and agricultural land deteriorates. This trend represents a continuity with the Soviet organization of space. The revival of agriculture is characteristic of only of a few areas that feature favorable natural conditions and is based on the emergence of new modernized enterprises. We discuss the contradiction between modernization, the polarization of active space and the use of historical heritage. Special
\end{abstract}


attention is paid to the role of human potential in the emergence of local growth points. In conclusion, we consider the possibilities of not only the reproduction and modernization of previous types of development, but also the emergence of new functions, including recreational landscape-cultural and seasonal dacha development.

Keywords: early developed region, spatial socio-economic polarization, settlements, industry, agriculture, residents and labor migration, summer residence (dachas), Yaroslavl Oblast

\section{References}

Averkieva K.V., Nefedova T.G. (2016) Dachnaya "kolonizatsiya rossiiskoj glubinki. Primer Kostromskoj oblasti [Dachas and the Colonization of Rural Areas by Urban Citizens in Russia: The Case of the Kostroma Region]. Mir Rossii, vol. 25, no 1, pp. 103-128.

Barinov S.L. (2007) Sotsialno-ekonomicheskaya peripheriinost' v staroosvoennykh regionakh Tsentra i Severo-Zapada Rossii [Socio-economic Peripherality in the Old-developed Regions in the Center and North-West of Russia]. Regional Studies, no 3(13), pp. 26-32.

Bessolitsyn A.A., Kuzmichev A.D. (2006) Ekonomicheskaya istoriya Rossii: ocherki razvitiya predprinimatelstva [Economic History of Russia: Essays on the Development of Entrepreneurship], Moscow: HSE.

Demographicheskie protsessy $v$ Yaroslavskoj oblasti za 60 let [Demographic Processes in the Yaroslavl Region for 60 Years] (1996), Yaroslavl: The Yaroslavl regional Committee of the state statistics.

Friedmann J. (1966) Regional Development Policy. A Case Study of Venezuela, Cambridge: Mass. Inst. Tech. Press.

Gibbs J. (1963) The Evolution of Population Concentration. Economic Geography, no 2, pp. 119-129.

Goroshnikov V.V. (ed.) (2018) Yaroslavskij kharakter [Yaroslavl Character], Rybinsk: Mediarost.

Gritsayj O.V., Ioffe G.V., Treyvish A.I. (1991) Tsentr $i$ peripheriya v regionalnom razvitii [Center and Periphery in Regional Development], Moscow: Nauka.

Ioffe G.V. (1990) Sel'skoe khozyajstvo Nechernozemya. Territorial'nye problem [Agriculture of the non-Chernozem Region: Territorial Problems], Moscow: Nauka.

Karachurina L.B., Mkrtchyan N.V. (2016) Rol' migratsii v usilenii kontrastov naseleniya na menitsipalnom urovne v Rossii [The Role of Migration in Enhancing Settlement Contrasts at the Municipal Level in Russia]. Izvestiya RAS. Series Geography, no 5, pp. 46-59.

Manakov A.G. (2014) Metodika istoriko-geographicheskogo rayonirovaniya staroosvoennyh territorii na mikrourovne (na primere Pskovskoi oblasti) [Methods of Historical and Geographical Zoning of Early Developed Territories at the Micro Level (The Case of Pskov Oblast)]. Pskov Regionological Journal, no 19, pp. 83-96.

Mkrtchyan N.V. (2019) Migratsii v selskoj mestnosty Rossii: territorialnye razlichiya [Migration in Rural Areas of Russia: Territorial Differences]. The Population and the Economy, no 1(3), pp. 39-51. DOI: 10.3897/popecon.3.e34780

Narodnoe khozyajstvo Yaroslavskoj oblasti in 1990 [National Economy of Yaroslavl Oblast in 1990] (1991). Statistical book, Yaroslavl: Yaroslavl regional Department of statistics.

Nefedova T.G. (2013) Desyat' aktualnykh voprosov o selskoj Rossii. Otvety geographa [Ten Topical Questions about Rural Russia. Geographer's Answers], Moscow: URSS-LENAND.

Nefedova T.G. (2017) Dvadstat' pyat' let postsovetskomu selskomu khozyajstvu v Rossii: geographicheskie trendy i protivorechiya [Twenty-five Years of Post-Soviet Russian Agriculture: Geographic Trends and Contradictions]. Izvestiya RAS, Series Geography, no 5, pp. 7-18. DOI: 10.7868/S0373244417050012 
Nefedova T.G., Averkieva K.V., Makhrova A.G. (eds.) (2016) Merzdu domom i... domom. Vozvratnaya prostranstvenaya mobilnost'naseleniya Rossii [Between Home and ... Home. Return Spatial Mobility in Russia], Moscow: New khronograph.

Nefedova T.G., Treivish A.I. (2017) Perestroika rasseleniya v sovremennoj Rossii: urbanizatsiya ili desurbanizatsiya? [The Restructuring of Settlement in Modern Russia: Urbanisation or de-Urbanisation?]. Regional Studies, no 2(56), pp. 12-23.

Pivovar G.A., Alekseev A.I., Gavrilenko A.S., Gusakov T.Yu., Delva K.I., Koryukhin D.M. (2018) Rost polifunktsionalnosti sel'skoj mestnosti: primer rajona na granitse Moskovskoj aglomeratsii [The Growth of Rural Multi-functionality: the Case of a District at the Edge of Moscow Agglomeration]. MSU Vestnik, Series Geography, no 2, pp. 102-104.

Privalovskaya G.A., Tarhov S.A., Treyvish A.I. et al. (eds.) (1995) Territorial'naya struktura khozyajstva staroosvoennykh rajonov [Economy Territorial Structure for the Earlydeveloped Regions], Moscow: Nauka.

Regiony Rossii [Regions of Russia] (1996), Moscow Federal service of state Statistics.

Regiony Rossii [Regions of Russia] (2018), Moscow Federal service of state Statistics.

Rybnikov A.A. (1929) Perenaselenie i bor'ba s nim [Overpopulation and the Battle against It]. Economic Geography. Vol. II. Soviet Union (ed. Baranskii N.N.), Moscow: Publishing house of Ya. Sverdlov Univ., pp. 60-111.

Saushkin Yu.G. (1947) Geographicheskie ocherki prirody i sel'skokhozyajsnvennoj deyatel'nosti naseleniya $v$ razlichykh rajonakh Sovetskogo Soyuza [Geographical Essay on the Nature and Agricultural Activities in Various Areas of the Soviet Union], Moscow: OGIZ.

Shagayda N.I., Uzun V.Ya. (2019) Drajvery rosta i strukturnykh sdvigov v sel'skom khozyajstve [Drivers of Growth and Structural Shifts in Russian Agriculture], Moscow: Delo.

Smetanin S.I. (2005) Istoriya predprinimatel'stva v Rossii: kurs lektsij [History of Entrepreneurship in Russia: a Course of Lectures], Moscow: Logos.

Smirnyagin L.V. (2016) Sud'ba geographicheskogo prostranstva V sotsial'nykh naykakh [The Future of Geographical Space in Social Sciences]. Izvestiya RAS, Series Geography, no 4, pp. 7-19. DOI: 10.15356/0373-2444-2016-4-7-19

Streletskij V.N. (ed.) (2019) Staroosvoennye rajony: genesis, istoricheskie sud'by, sovremennye trendy rasvitiya [Early-developed Regions: Genesis, Historical Destinies, Modern Development Trends], Moscow: IP Matushkin.

Top 50: Samye turisticheskie regions Rossii, populyarnye v 2017 gody [Top 50: The Most Popular Tourist Regions of Russia in 2017]. TurStat. Available at: http://turstat.com/travelrussia2017, accessed 15.10.2020.

Treivish A.I. (2010) «Srzatie» prostranstva: tractovka i modely ["Shrinkage" of Space: Interpretation and Models]. Shrinkage of Socio-economic Space: New in the Theory of Regional Development and Practice of Its State Regulation (ed. Artobolevskij S.S., Sintserov L.M.), Moscow: Eslan, pp. 16-32.

Treivish A.I. (2016) Mobil'nost' i razvitie obshchestva v pulsiruyushem prostranstve [Mobility and Development of Society in a Pulsating Space]. Geography of World Development. Issue 3: Collection of Scientific Papers (ed. Sintserov L.M.), Moscow: Partnership of scientific publications KMK, pp. 16-39.

Vserossiiskaya sel'skokhozyajstvennaya perepis' 2016 [All-Russian Agricultural Census 2016] (2017), vol. 2, Moscow: Statistics of Russia.

Yaroslaviya - goroda i rajony oblasti za 2018 [Yaroslaviya - Cities and Districts of the Region in 2018] (2019), Yaroslavl: Terra. organ Feder. state services. statistics for the Yaroslavl region.

Yaroslavskaya guberniya. Spisok naselennykh mest po svedeniyam 1859 goda [Yaroslavl' Province: the List of Localities According to Data from 1859] (1865), Saint Petersburg: Printing house of Karl Wulf. 